\title{
An Innovative Approach to Educating Students on Manufacturing
}

\author{
Murali Krishnamurthi, Mohamed I. Dessouky \\ Northern Illinois University
}

\section{INTRODUCTION}

The accelerated rate at which new technologies are being introduced today has created a large demand for people competent in the new technologies. The widening gap between the steady rise in the level of skill requirements and the reduced availability of people with these skills is making it difficult for U. S, industries to compete in the international market. To function effectively in today's technological society, contribute to its growth, reap its benefits, and minimize its hazards, knowledge of the technology is essential. This is true whether one is pursuing a career in business, economics, law, education, health care, mathematical, physical or social sciences, humanities or the arts.

Academic institutions, particularly engineering schools, have the primary responsibility for producing new graduates in sufficient numbers and with adequate knowledge of science and technology and skill to meet the needs of the industry and the society. However, educators are often faced with more than the mere challenge of conveying technical information to their students. The rate of attrition and loss of interest in learning among first and second year students are significant and require innovative curricula and course designs to counter these problems. The disproportionate number of female and minority students in engineering majors compared to non-engineering majors also deserves attention.

Numerous journal articles, books, and studies have emphasized the need for providing students with the necessary exposure to manufacturing concepts and motivating them to prepare themselves adequately for the technological challenges ahead $[3,9,14]$. In order to meet these needs, and hopefully, to attract more students to engineering programs and retain them, first and second year university students should be given the opportunity take a course on manufacturing systems.

Educating first and second year students on manufacturing concepts and applications requires a careful design of course content, level and depth of coverage, and teaching methods. Course contents must be broad enough to cover the scope of activities in manufacturing systems and to relate them to basic science and mathematics without diluting the depth of coverage. Again a balance must be maintained between theoretical analysis and application in order to keep the students challenged, but not discouraged. Finally, appropriate teaching methods should be chosen for the specific topics covered.

Traditionally, the primary qualification for engineering educators has been advanced degrees and/or industry experience and very little training in teaching techniques has been expected of them. However, the knowledge of teaching techniques, students' learning styles, and the consequences of a mismatch between 
those two are increasingly becoming a necessity to convey the material effectively and to make the courses more interesting to a student body with diverse skills and interests. This knowledge is especially necessary to attract into engineering majors those capable students who would not otherwise choose an engineering major.

In this paper, an introductory course on manufacturing systems, tailored for a non-engineering student body, is proposed as a solution for addressing the needs mentioned above. The innovative design of this course along with the details of its ongoing development are discussed in this paper.

\section{THE NEED FOR FOCUSING ON TEACHING AND LEARNING TECHNIQUES}

The literature on curriculum design and development generally emphasizes that the instructional goals and objectives should be specified to include three domains of learning, namely, the cognitive, the affective, and the psychomotor, wherever applicable $[1,2,11,12]$. To achieve the instructional goals and objectives fully and to have a long-lasting impact on the students, curriculum researchers recommend that the educational objectives under all three domains be included in curriculum and course design. Satisfying the objectives under the three domains requires matching learning and teaching styles [5]. When mismatches occur between teaching and learning styles, it becomes difficult to satisfy the instructional goals and objectives. Most current teaching tends to be abstract, verbal, deductive, and sequential, and students tend to be passive. Felder and Silverman $[5,6]$ have concluded that all combinations of teaching and learning styles are needed in an engineering curriculum to reach all student types.

The recommendations of Felder and Silverman are also echoed by Kolb in his four-stage learning cycle. Working with engineering students at MIT, Kolb developed a model of experiential learning that provides a framework for understanding learning styles [1 O, 13]. Kolb organized the elements of learning and learning styles into four quadrants as shown in Figure 1 with the ends of the quadrants as concrete experience (feeling) versus abstract conceptualization (thinking), and reflective observation (watching) versus active experimentation (doing). Kolb identified four distinct learning styles that fall in those four quadrants as: divergers (Type 1 learners); assimilators (Type 2 learners); converges (Type 3 learners); and accommodators (Type 4 learners) [7]. Studies by Claxton and Ralston [4] have shown that $10 \%$ of undergraduate students are Type 1 learners, 40\% are Type 2 learners, 30\% are Type 3 learners, and 20\% are Type 4 learners.

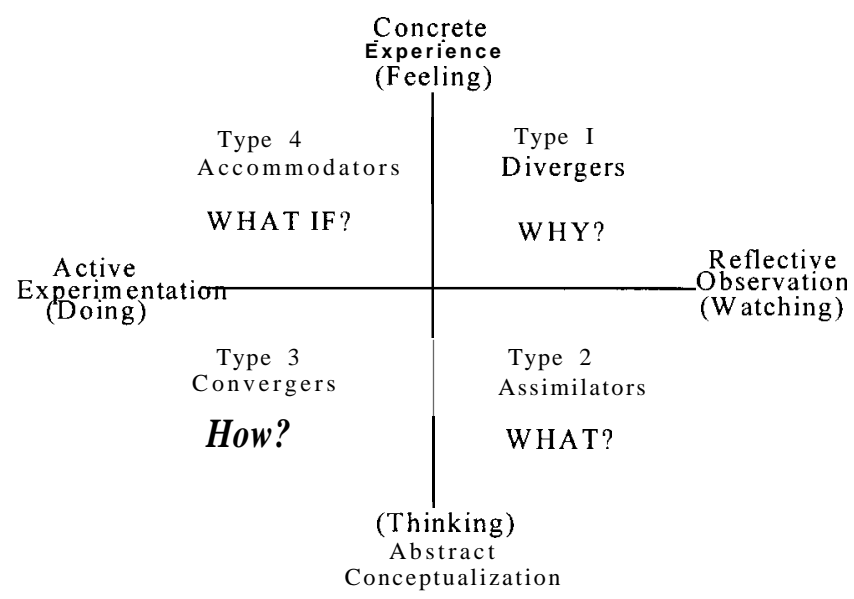

Figure 1. Four Quadrants of Learning and Learning Styles [7, 10]
Similar to students' learning styles, teachers also have preferred teaching styles which also can impact a course and the information conveyed to the student. Claxton and Ralston classified teaching styles under four different categories as: Type 1, Type 2, Type 3, and Type 4 teachers. Type 1 teachers focus upon the personal development of students and tend to be highly motivational and have good relations with their students and their teaching styles usually involves questioning and class discussion. Type 2 teachers focus primarily on the transmission of knowledge in a hierarchical manner from teacher to the student and their teaching style is professor-centered lectures. Type 3 teachers primarily

focus on promoting productivity and competence and want their students to acquire the necessary skills and be independent and their teaching style is usually the traditional lecture format coupled with laboratories and out- 
of-class room experiences. Type 4 teachers encourage experiential learning, self-discovery, and are generally stimulating, and hope to expand students' intellectual boundaries.

- Claxton and Ralston have concluded from their studies of engineering faculty that $10 \%$ are of Type 1 , $50 \%$ are of Type 2, 30\% are of Type 3, and 10\% are of Type 4 . These results illustrate that the professordominated teaching style is the most prevalent one in engineering curriculum and that the faculty do not generally pay attention to the different learning styles of students in their courses. If the goal is to reach a majority of the students, motivate them to learn and understand, and convey the course material effectively, then the course or curriculum should be designed to address the issues mentioned above.

\section{DESIGN OF AN INTRODUCTORY COURSE ON MANUFACTURING SYSTEMS}

Manufacturing enjoys a unique position among the different applications technology. It touches the lives of people in modern society in almost every aspect: as producers, consumers, suppliers, and objects of its environmental and societal impact. Particularly, a significant section of the society provides a vital support to the manufacturing industry in the form of technical, informational, financial, legal, and artistic expertise, as well as services related to the development of human resources and the sale of products. Manufacturing differs from the established engineering disciplines, such as mechanical and civil engineering, which are defined traditionally in terms of both educational degree and specialized expertise. Manufacturing is, in contrast, more defined by the functions performed and demands multidisciplinary capabilities. It is also an integrative field, bringing together concepts from the physical and material sciences that deal with equipment and tools, with concepts from the biological and social sciences that deal with human factors as ergonomics, and tying them together with the use of mathematical modeling and principles of management applied to production. In view of this, students with diverse skills and interests can readily relate to this field.

The course design consists of three dimensions, namely, (1) Manufacturing Concepts, (2) Learning Preferences, and (3) Teaching Methods. Students are introduced to manufacturing system concepts using basic principles in algebra, physics, and chemistry, in addition to introductory statistics and other mathematical and scientific principles. The teaching methods include lectures, videos, laboratory experiments, creative design exercises, problem solving sessions, and group projects to meet the needs of different learning styles. Homework assignments and tests help to assess the degree to which students learn the subject matter. The course material has been designed and developed in the form of modules to integrate properly into a welldefined framework. Each module covers a specific topic and consists of an appropriate mix of teaching and learning methods to motivate the students to learn, understand, and appreciate the material.

This course is designed to cover the various activities of the manufacturing system throughout the product life cycle, from management (finance, human resource development, administration), marketing (forecasting, sales, advertisement), design and development (conceptual design, preliminary design, detailed design), through manufacturing (material conversion, handling, process planning, production and quality control), distribution (transportation and storage), and utilization (consumption, maintenance, replacement). Manufacturing concepts are introduced in this course at a broader level, emphasizing the major functions of a manufacturing enterprise, and the product life cycle, as defined by Barrington, Jr. [8] as: (1) Manage the enterprise, (2) Manufacture the products, (3) Market the products, and (4) Support Corporate Activities.

In traditional manufacturing courses offered for engineering majors, the emphasis is usually placed on the manufacture of products; in those offered for business majors, the emphasis is placed on one or more of the other three functions. However, in this course, topics that cover all of the above four functions are included to 
show the students a global view of manufacturing and also its opportunities for those in disciplines other than engineering. A sample list of the topics that are covered in this course is as follows:

- Life Cycle of a Production System

- Manufacturing Processes

- Planning for Production

- Operations Scheduling

- Manufacturing and the Environment
- Product Design and Development

- Materials Engineering

-Quality Control

- Manufacturing Automation

- Ergonomics in Manufacturing

One of the advantages of integrating the preferred learning and teaching styles into an introductory course on manufacturing is that manufacturing concepts are ideal for such a course design compared to pure theory-oriented topics. Manufacturing concepts can be introduced to students through motivational issues (Why?), formal lectures on facts and information (What?), application examples and experiments (How?), and exercises in synthesis and evaluation (What if?) and all homework exercises assigned in this course are designed to cover these 4 quadrants.

\section{CONCLUSIONS}

In this paper, an introductory course on manufacturing systems has been proposed as a key for motivating students. This course gives students the opportunity to learn, appreciate, and understand the role manufacturing plays in today's society and the potential it has for career opportunities. The emphasis placed on teaching and learning styles in this course helps to dispel students' fear of science and engineering and motivate them to choose an engineering major. This especially has a positive impact on women and minority students who are often turned off by science and engineering due to lack of encouragement and paucity of confidence-building courses. This course gives them the positive experience they badly need and help them become the role models for attracting other women and minorities students into engineering programs.

This course also gives students the motivation and the reason for learning basic mathematics, physics, chemistry and other science topics. Since these basic math and science topics are essential to understanding manufacturing concepts, students are also able to appreciate the fundamental knowledge and prepare themselves adequately for advanced courses. This course serves as a vehicle for non-engineering students to experience and explore what engineering has to offer without actually $\mathrm{j}$ oining an engineering program.

This course is currently being offered as a general education course to non-engineering students at Northern Illinois University and has attracted both male and female students from business, computer science, art, economics, and technology. The course material is continuously being improved with the support of a Curriculum and Course Development Grant from the National Science Foundation awarded to the authors.

\section{REFERENCES}

[1] Armstrong, R. J. et al. "The Development and Evaluation of Behavioral Objectives," Charles A. Jones Publishers, Worthington, Ohio 1970.

[2] Bloom, B. S. "Taxonomy of Educational Objectives: The Classification of Educational Goals: Handbook I: Cognitive Domain,” Longman Publishers, White Plains, New York, 1956.

[3] Botkin, J. et al. "High Technology, Higher Education, and High Anxiety," Technology Review, October 1982. 
[4] Claxton, C. S. and Ralston, Y. "Learning Styles: Their Impact on Teaching and Administration," ỂंIC, Washington, D. C., 1978.

[5] - Felder, R. M., and Silverman, L. K. "Learning and Teaching Styles in Engineering Education," Journal of Engineering Education, 78 (7), 674-681, April 1988.

[6] Felder, R. M., and Baker-Ward, L. "How Engineering Students Learn, How Engineering Professors Teach, and What Goes Wrong in the Process," Proceedings of Frontiers in Education Conference, Vienna, Austria, July 1990.

[7] Harb, J. N., and Terry, R. E. "Teaching Through the Cycle: Application of Learning Style Theory to Engineering Education at Brigham Young University," Department of Chemical Engineering, Brigham Young University, 1992.

[8] Barrington, Jr., J. "Understanding the Manufacturing Process - Key to Successful CAD/CAM Implementation,” Marcel Dekker, Inc., New York, 1984

[9] Hayes, R. H. and Wheelwright, S. C. "Restoring Our Competitive Edge: Competing Through Manufacturing," John Wiley \& Sons, New York, 1984.

[10] Kolb, D. A. "Experiential Learning: Experience as the Source of Learning and Development," Prentice-Hall, Englewood Cliffs, New Jersey, 1984.

[11] Krathwohl, D. R., Bloom, B. S., and Masia, B. B. "Taxonomy of Educational Objectives: The Classification of Educational Goals: Hand Book II: Affective Domain," Longman Publishers, White Plains, New York, 1964.

[12] Oliva, P. F. "Developing the Curriculum,” 3rd Edition, Harper Collins Publisher, New York, 1992.

[13] Stice, J. E. "Using Kolb's Learning Cycle to Improve Student Learning," Journal of Engineering Education, 291-296, February 1987

[14] Van Valkenburg, M. E. "Preparing the Engineers Of the21 st Century," Journal of Engineering Education, 103, November 1988.

\section{MURALI KRISHNAMURTHI}

Murali Krishnamurthi is an Assistant Professor in the Department of Industrial Engineering at Northern Illinois University. He received his Ph.D. in Industrial Engineering from Texas A\&M University. His teaching and research interests are in Simulation, Manufacturing, Operations Research, and Information Systems.

\section{MOHAMED I. DESSOUKY}

Mohamed I. Dessouky is the Chair and Professor in the Department of Industrial Engineering at Northern Illinois University. He received his Ph.D. in Industrial Engineering from The Ohio State University. His teaching and research interests are in Discrete Optimization, Production Planning, Scheduling and Control, Simulation, Integrated Quality Systems, and Project Management. 